\title{
Toward a New Geography of Hasidism
}

\author{
MARCIN WODZIŃSKI ${ }^{\mathrm{a}}$ AND URIEL GELLMAN ${ }^{\mathrm{b}}$ \\ ${ }^{a}$ University of Wroctaw, Wroctaw, Poland \\ E-mail:wodzinsk@uni.wroc.pl \\ ${ }^{b}$ Hebrew University of Jerusalem, Jerusalem, Israel \\ E-mail: uriel.gellman@mail.huji.ac.il
}

\begin{abstract}
The geography of Hasidism has long been one of the most contentious issues in the history of the movement. This article represents an attempt to free hasidic geography from outmoded preconceptions by proposing a new conceptualization of the hasidic leadership and its following in Eastern Europe. Based on an original, extensive database of hasidic centers, the authors drew five maps in sequence showing the development of Hasidism from its inception to the Holocaust. The five periods into which the database is divided are demarcated by four historically significant landmarks: the years 1772, 1815, 1867, and 1914. The article offers some possible interpretations of the maps, and draws a number of conclusions arising from them. The authors examine the dynamics and tendencies of the expansion of the movement within geographical frameworks, including the shift of hasidic centers from Podolia and Volhynia in the eighteenth century to Galicia and the southeastern provinces of Congress Poland in the nineteenth century, and subsequently to Hungary and Romania in the twentieth century; hasidic penetration into Jewish Eastern Europe, reaching its peak in the period between 1815 and 1867; and the metropolization of the hasidic leadership after 1914. The article also analyzes the patterns of concentration and diffusion of the hasidic leadership, and the impact of political factors upon these parameters.
\end{abstract}

Keywords Hasidism · Eastern Europe · Geography · Demography · Expansion · Metropolization

The geography of Hasidism has long been one of the central and most contentious issues in the history of the movement. The two most frequently debated questions are the geographical dimension of hasidic expansion and the

\footnotetext{
An earlier version of this paper was presented at the London conference, Toward a New History of Hasidism, organized by the Institute of Jewish Studies at University College, London, in April 2009. We are grateful to the participants of the conference for their criticism and suggestions. We also would like to thank Shaul Stampfer for his valuable remarks on an earlier draft of this paper and Michael Silber for his assistance in converting from Yiddish several of the Hungarian and Romanian place names. Many thanks to Gideon Biger for correcting our use of historical geography technical terms. Last but not least, we are most grateful to Ada Rapoport-Albert and Moshe Rosman for their extremely helpful assistance in the process of editing this article.
} 
regional characteristics of various hasidic groups. ${ }^{1}$ While certain aspects of both questions, such as the western border of Hasidism or its regional demography, have been touched on by several historians, the issue as a whole has never been thoroughly and systematically addressed. This has had farreaching consequences for research on the demography of hasidic expansion, which, in turn, has shaped our notion of the geography of Hasidism. Jewish historiography has traditionally assumed that Hasidism soon achieved demographic dominance in most of the eastern European territories. As Simon Dubnow put it, by the beginning of the nineteenth century, "Hasidism had conquered almost all the communities of the Ukraine and eastern Galicia, most of the communities of central Poland, and a considerable number of communities in Romania and Hungary." 2 Only in Lithuania and Belarus did Hasidism fail to achieve an absolute victory. Recent research, however, indicates that these highly inflated estimates are very far from reality and, more importantly, cannot be traced to any verifiable data or reliable research. While it is possible that already by the turn of the nineteenth century, the emerging hasidic movement achieved a certain measure of influence in a few localities, we have no data to suggest any general observations of this kind, and certainly not to justify the claim of Hasidism's sweeping conquest of eastern Europe. The few reliable data we do possess indicate, for example, that as late as the 1820 s, the hasidim may have constituted no more than ca. 10 percent of the Jewish population of central Poland. ${ }^{3}$ Similar proportions emerge from the data for the Minsk province in Belarus during the 1850s. ${ }^{4}$ Although

\footnotetext{
${ }^{1}$ For the most important publications dealing with hasidic geography see Simon Dubnow, Toledot hahasidut (Tel Aviv, 1967), 76-7, 107, 215, 325-6, 441-3; Aaron Zeev Aescoly, Hahasidut bepolin (Jerusalem, 1998), 34-6; Avraham Greenbaum, "Hitpashtut hahasidut bame'ah ha-19: mabat sotsyo-geografi rishoni," Hakongres ha'olami lemada'ei hayahadut 10:B,1 (1990), 239-43; Adam Teller, "Hasidism and the Challenge of Geography: The Polish Background to the Spread of the Hasidic Movement," AJS Review 30, no. 1 (2006), 1-29. For the pitfalls of the dominant concepts of the geography of Hasidism, see David Assaf, “'Hasidut Polin' o 'Hasidut bepolin'? Leva'ayat hageografyah hahasidit," Gal-Ed 14 (1995), 197-206. See also David Assaf and Gadi Sagiv, "Hasidism in Tsarist Russia: Historical and Social Aspects" in the present volume.

${ }^{2}$ Simon Dubnow, Toledot hahasidut, 3.

${ }^{3}$ On the difficulty of interpreting demographic data relating to Hasidism, see Marcin Wodziński, "How many Hasidim were there in Congress Poland? On the Demographics of the Hasidic Movement in Poland during the First Half of the Nineteenth Century," Gal-Ed 19 (2004), 13-49; id., "How Should We Count Hasidim in Congress Poland? A Response to Glenn Dynner," Gal-Ed 20 (2006), 105-21; Glenn Dynner, Men of Silk: The Hasidic Conquest of Polish Jewish Society (Oxford and New York, 2006), 40-53; id. "How Many Hasidim Were There Really in Congress Poland? A Response to Marcin Wodziński," Gal-Ed 20 (2006), 91-104.

${ }^{4}$ Barbara Stępniewska-Holzer, "Ruch chasydzki na Białorusi w połowie XIX wieku," Kwartalnik Historii Żydów 3 (2003), 511-22.
} 
these data do not as yet enable us to produce a more general and dynamic picture of the demographic expansion of Hasidism, they do provide strong enough indications to call into question all the existing estimations, highlighting the need for fresh research and a new methodological approach to the subject.

This research weakness underlies all the available maps of Hasidismtraditionally the most popular mode of presenting hasidic geography. The majority of these maps, which are largely reliant on each other (if only inasmuch as they share a common conceptual foundation), reflect an impressionistic view of the territorial scope of Hasidism, marking in only the places of residence of the most famous hasidic leaders, or the areas in which the major hasidic dynasties were dominant. ${ }^{5}$

The essential defect of all these maps is twofold. First, they depict a static and synchronic picture, without any consideration for the chronological development of Hasidism, merging in one map centers dating from the mideighteenth to the mid-twentieth century. This inevitably obscures the historical dimension of a movement, which has, after all, unfolded over two and a half centuries, by reducing it to a cluster of timeless personalities, all seemingly active simultaneously.

Second, the criteria for selecting the hasidic centers to be included in such maps are purely impressionistic, usually based on subjective judgments as to the importance of this or that hasidic leader or dynasty. Even if one agrees with the particular selection made in any one of these maps, it is not clear to what extent it reflects hasidic political and social realities. Does it, for example, correlate the places of residence of the hasidic leaders with centers of hasidic demographic, political, or social dominance? Are the selected localities hasidic pilgrimage sites or were they densely populated by hasidic followers? None of the maps addresses these uncertainties, and it is not at all clear what they actually show. ${ }^{6}$

These weaknesses have prompted us to look for an alternative conceptualization of hasidic geography, with the aim of creating a more meaningful-

\footnotetext{
${ }^{5}$ See, e.g., the maps of Hasidism in Encyclopaedia Judaica (Jerusalem, 1971), 7:1392; Yosef Shapiro, Atlas histori shel am yisra'el (Tel-Aviv, 1966), no. 59; Elie Barnavi, A Historical Atlas of the Jewish People (New York, 1992), 162-3; Czas chasydów: The Time of the Hasidim, ed. Elżbieta Długosz (Kraków, 2005), 10; Anna Walaszczyk, Tajemniczy świat chasydów: W królestwie mistycyzmu, kabaty, śpiewu, tańca i ekstazy (Łódź, 2009), 29.

${ }^{6}$ Sometimes, more sophisticated maps include graphs indicating the alleged directions of hasidic expansion. See, for example, Marvin I. Herzog, The Yiddish Language in Northern Poland: Its Geography and History (Bloomington and the Hague, 1965), 22; Evyatar Friesel, Atlas of Modern Jewish History (Oxford, 1990), 51; Andrzej Żbikowski, Żydzi (Wrocław, 1997), 162-3. See also Shmuel Ettinger, "The Modern Period," in A History of the Jewish People, ed. Hayim Hillel Ben-Sasson (Cambridge, 1976), 771.
} 
dynamic-diachronic rather than static-synchronic-representation of the process of hasidic expansion. To this end we have set out our data in a sequence of chronological maps, for which there was some precedent in the more advanced of the existing maps of Hasidism. ${ }^{7}$ It was more difficult, however, to decide which hasidic centers to include in our maps, as this required not only a new source-base but also a new conceptual paradigm, one that would do justice to the hundreds of thousands of rank-and-file hasidim rather than maintaining the elitist focus on their leaders. In other words, we felt that an ideal map of Hasidism should represent the distribution of ordinary hasidic followers rather than simply noting their leaders' places of residence. However, given the limitations of the available sources, such a map must remain an unrealized desideratum for the foreseeable future. We have therefore decided to turn to source materials which, even though they do not enable us to overcome the elitist bias of the traditional historiography, still allow us to feature many more hasidic centers in our maps, and to base our selection on more rigorous criteria than the impressionistic category of important tsadikim.

In searching for a more objective and broader source-base for our maps, we have chosen the largest existing list of hasidic leaders, drawn from volume two of the Encyclopedia of Hasidism, published in three parts in 1986-2004 by Yitshak Alfasi. ${ }^{8}$ This encyclopedia is based on hasidic homiletic literature, hasidic hagiography, yizkor books, the Jewish periodical press, and occasionally (albeit too seldom) on modern academic historical research. Admittedly, the work is by no means free of deficiencies: many important details are missing, legendary tales are accepted uncritically as historical evidence, and factual errors are legion. Moreover, the social structure and cultural expressions of Hasidism are presented anachronistically, on the basis of outdated assumptions that are no longer tenable today. ${ }^{9}$ Nevertheless, what was important for us was the all-inclusive character of the work. Alfasi intended it to be a comprehensive collection of biographies, covering all known hasidic leaders, regardless of their relative importance. This is precisely what qualified his Encyclopedia to serve as our database source (even if it sometimes led him to include such figures as Shlomo Efrayim, the infant son

\footnotetext{
${ }^{7}$ For examples of such maps see, e.g., Dan Cohn-Sherbok, Atlas of Jewish History (London and New York, 1994), 126-31; Glenn Dynner, Men of Silk, 50-51; YIVO Encyclopedia of Jews in Eastern Europe (New Haven and London, 2008), 1:662, 665; 2:1183. All these maps still represent an impressionistic selection of hasidic centers, and, in most cases, no more than two maps are provided consecutively to cover Hasidism's full chronological span.

${ }^{8}$ Yitshak Alfasi, Ishim, vol. 2 of Entsiklopedyah lahasidut, 3 parts (Jerusalem, 1986-2004).

${ }^{9}$ Examples of this include the notion that hasidic memory and tradition are invariably and absolutely reliable, or that the hasidic leadership had always been hereditary and uncontroversial, and many other such anachronistic projections.
} 
of Nahman of Bratslav [Bracław], who died at the age of one). Despite all these lapses of academic rigor, the Encyclopedia, with its indiscriminateand thus, egalitarian - list of hasidic leaders, covering the movement's full chronological span, provided us with a source-base that was best suited for our purpose.

On that basis, we have built a database that is chronologically divided into five periods in the history of Hasidism. It includes the names of 1,786 hasidic leaders whose geographic locations we determined according to their main places of residence and/or activity. ${ }^{10}$ There are many more entries in Alfasi's Encyclopedia, but for the purpose of our project, we excluded individuals who did not function either as hasidic rebbes or as hasidic communal rabbis, ${ }^{11}$ as well as anyone whom the data did not identify clearly as hasidic. $^{12}$ In addition, we have not listed the tsadikim who spent most of their careers outside of eastern Europe, that is, in western Europe, North America or Palestine. Our map focuses exclusively on Hasidism in its eastern European birthplace.

The five periods into which our database is divided are demarcated by four historically significant landmarks: the years $1772,1815,1867$, and $1914 .{ }^{13}$ This has resulted in five consecutive maps (Maps. 1, 2, 3, 4, and 5) showing the development of Hasidism from its inception to the Holocaust. ${ }^{14}$ In all five

\footnotetext{
${ }^{10} \mathrm{We}$ have managed to identify more than 98 percent of the localities mentioned in the Encyclopedia. Since the number of tsadikim listed in it is large, the margin of error that may ensue from such mistakes as it contains, or from our own mistaken identification of some of the localities it mentions (which are often difficult to reconstruct from the purely consonantal or wrongly vocalized Hebrew spelling of the Encyclopedia) is relatively negligible. When a hasidic leader was active in more than one locality, we have listed only the place in which most of his activities occurred. When the duration of a tsadik's activity straddled two of our periods, we have listed only the longer of the two, unless the shorter one constituted more than a third of the duration of his career, in which case we listed him in both periods. However, such cases are so rare and statistically insignificant that they fall within the acceptable range of statistical error and have no effect on the overall interpretation of the data.

${ }^{11}$ We use the term hasidic rebbe or tsadik loosely, as referring to all hasidic leaders regardless of whether they functioned as tsadikim or only as communal rabbis who were known for or had declared their allegiance to Hasidism.

${ }^{12}$ This is the case with many pre-hasidic or non-hasidic rabbis listed in the Encyclopedia, as well as various others who never functioned as hasidic leaders, such as Nahman of Bratslav's infant son mentioned above, Edel, the Besht's daughter, or Nahman Tsvi of Kołomyja, who qualified for inclusion only due to the fact that according to a legendary source, the Besht himself had tested him as a child, which, according to Alfasi, granted him "the privilege of appearing in the glow of Hasidism" (Alfasi, Entsiklopedyah, Ishim, 3:465).

${ }^{13}$ This follows the periodization suggested by the editorial team of the projected New History of Hasidism, which convened as a research group of the Institute for Advanced Studies at the Hebrew University of Jerusalem in 2007-2008.

${ }^{14}$ The maps themselves were created by Dr. Witold Sienkiewicz, editor and cartographer of the Demart SA publishing house, in cooperation with the Museum of the History of Polish
} 


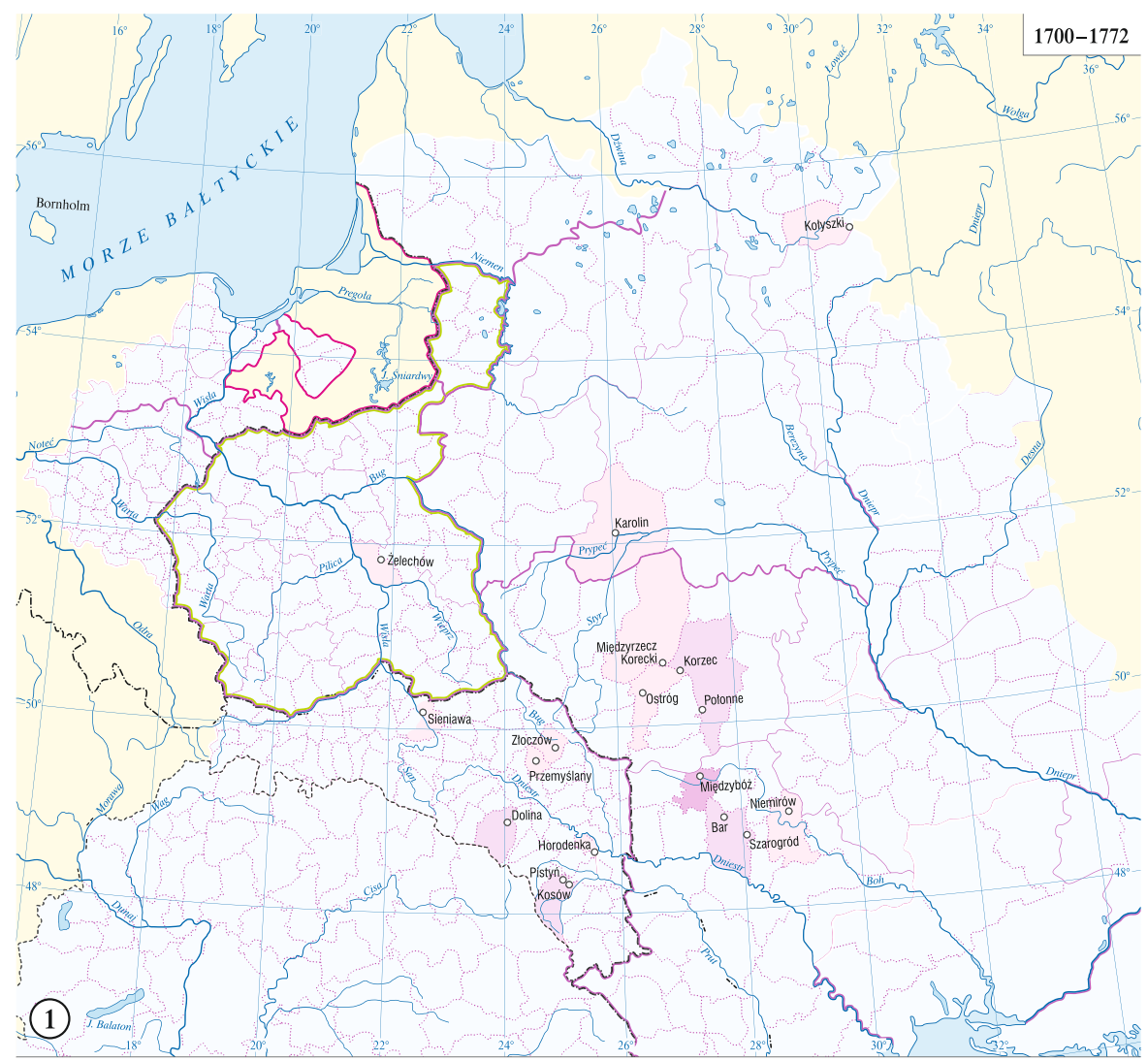

Map 1. Concentration of hasidic leaders by county, before 1772

\section{Legend for Maps 1-5}

Number of hasidic leaders by county

\section{$8-9 \square 10$ or more}

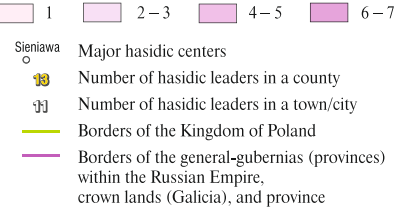

Borders of gubernias

2....... Borders of counties and equivalent administrative units

-..-- International borders

------ Borders of Hungary within the Austro-Hungarian Dual Monarchy

- Borders of the Polish-Lithuanian Commonwealth in 1772 within the Russian Empire,

- Borders of the Polish Republic in the interwar period, 1918-1939 


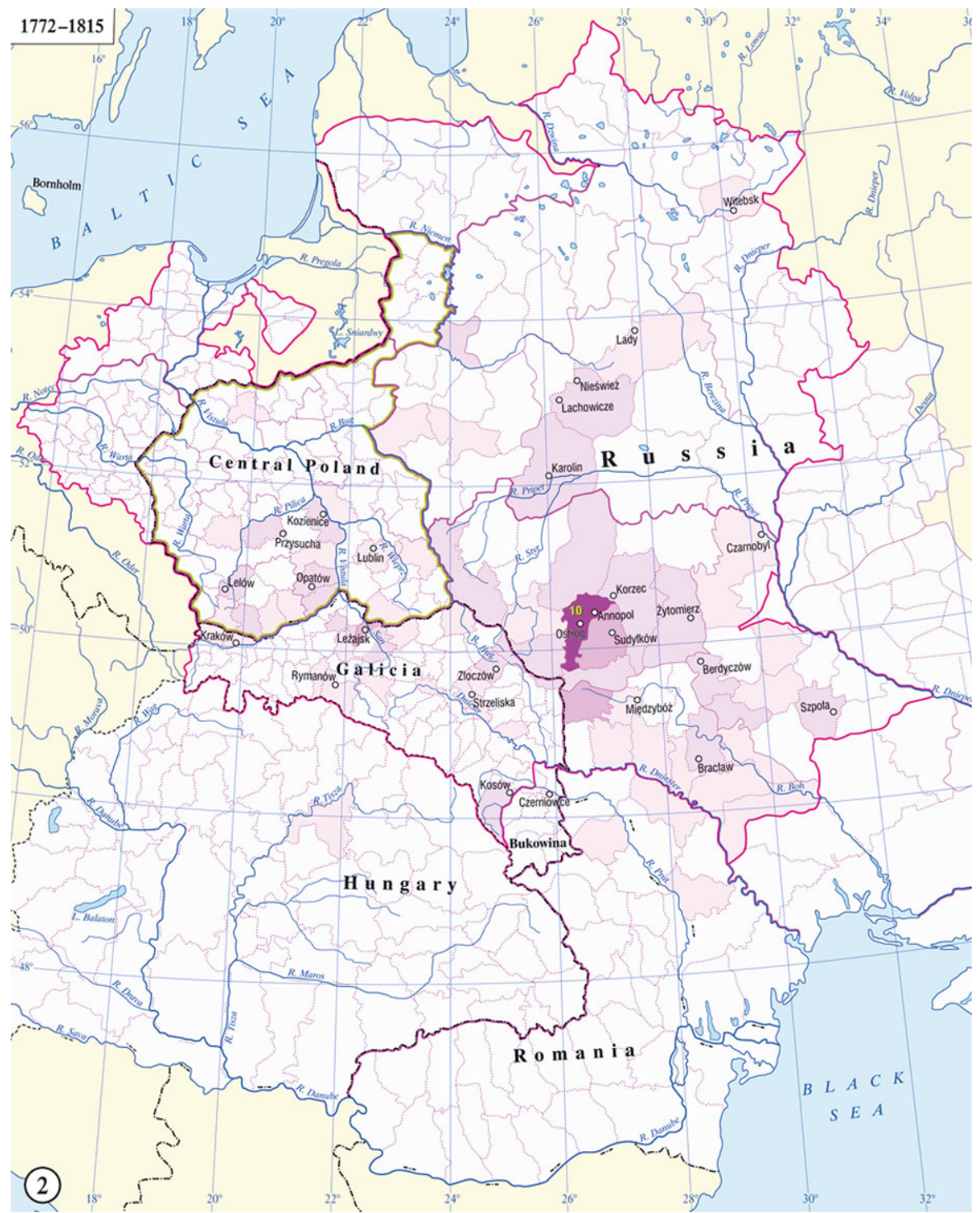

Map 2. Concentration of hasidic leaders by county, 1772-1815 


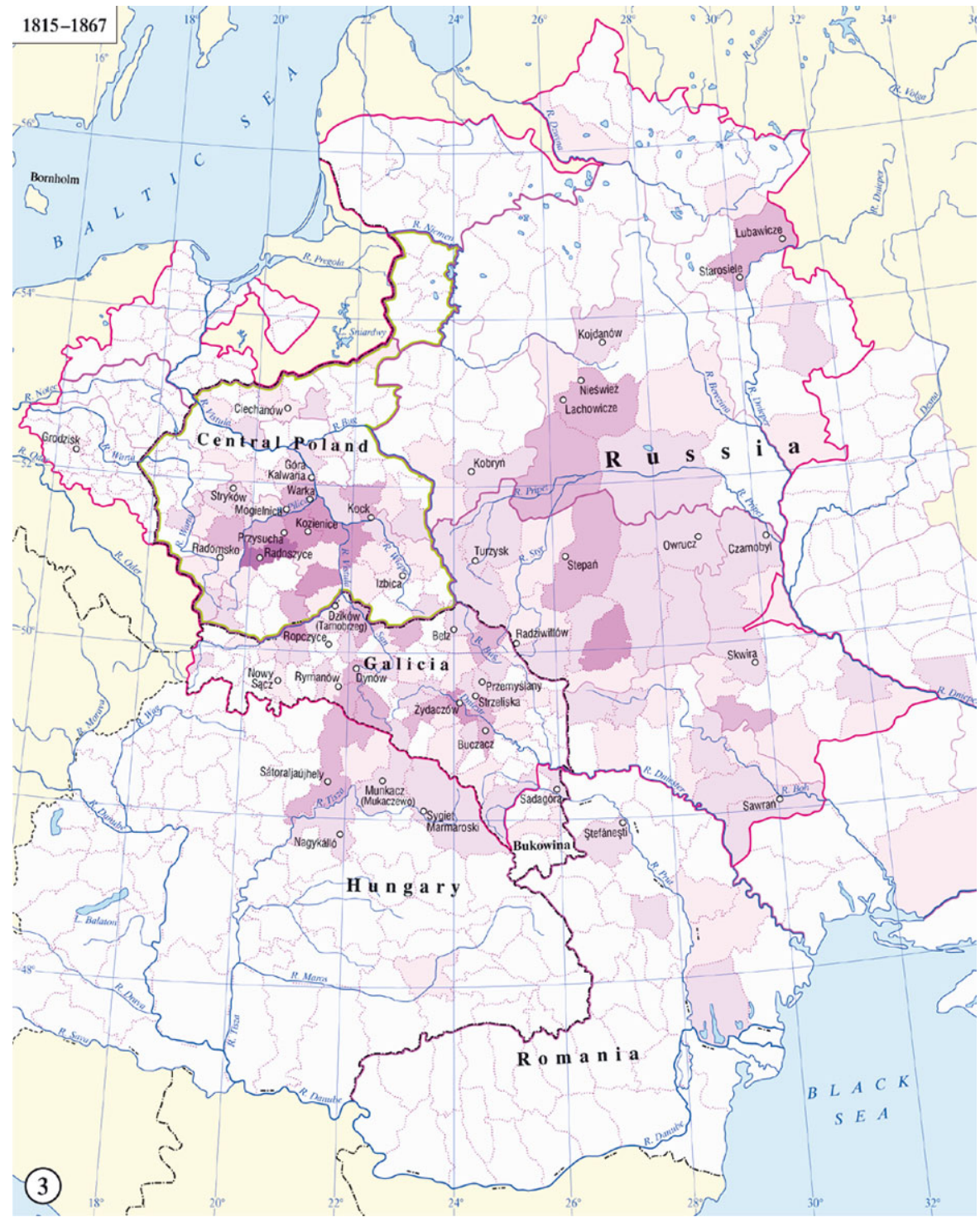

Map 3. Concentration of hasidic leaders by county, 1815-67 


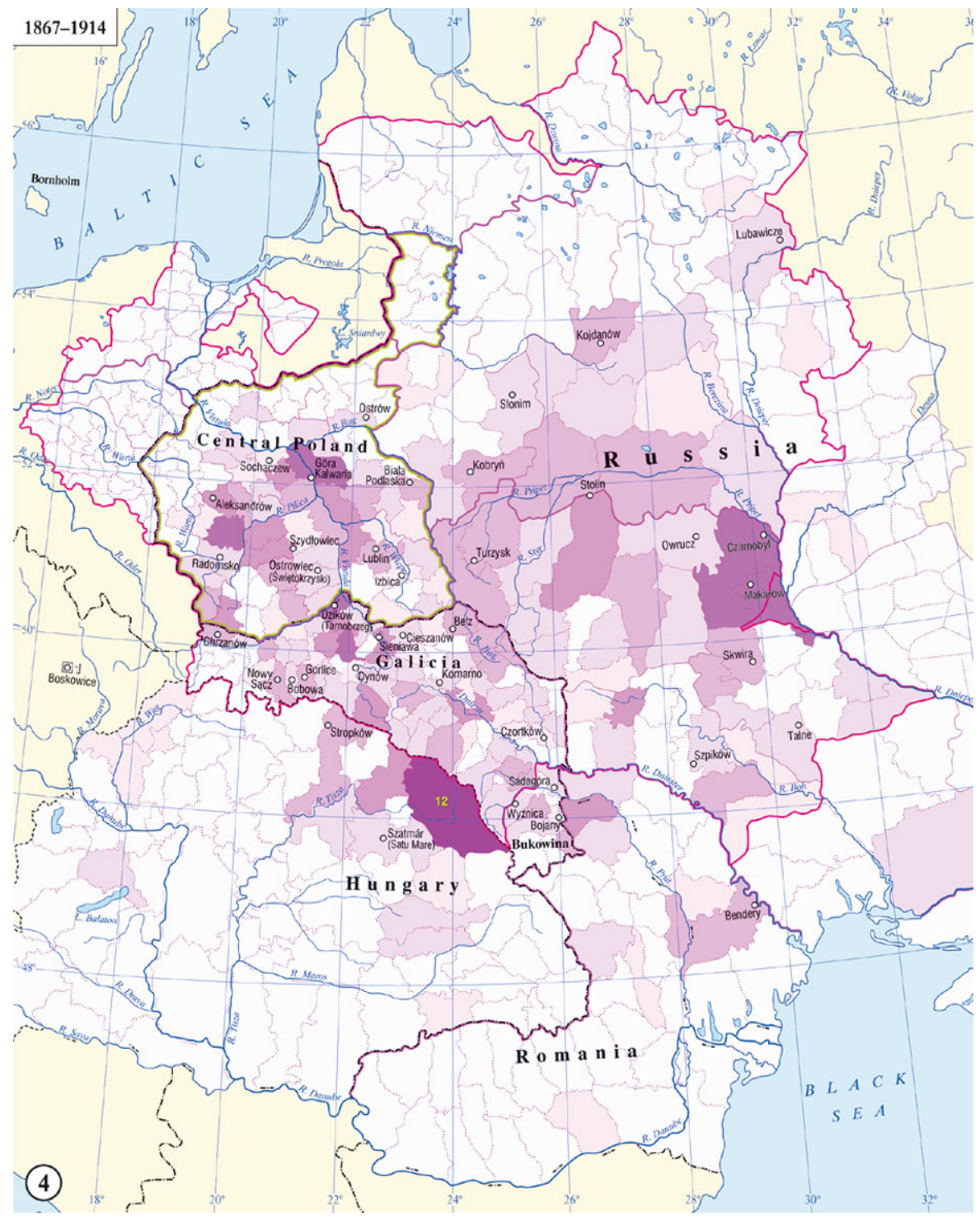

Map 4. Concentration of hasidic leaders by county, 1867-1914 


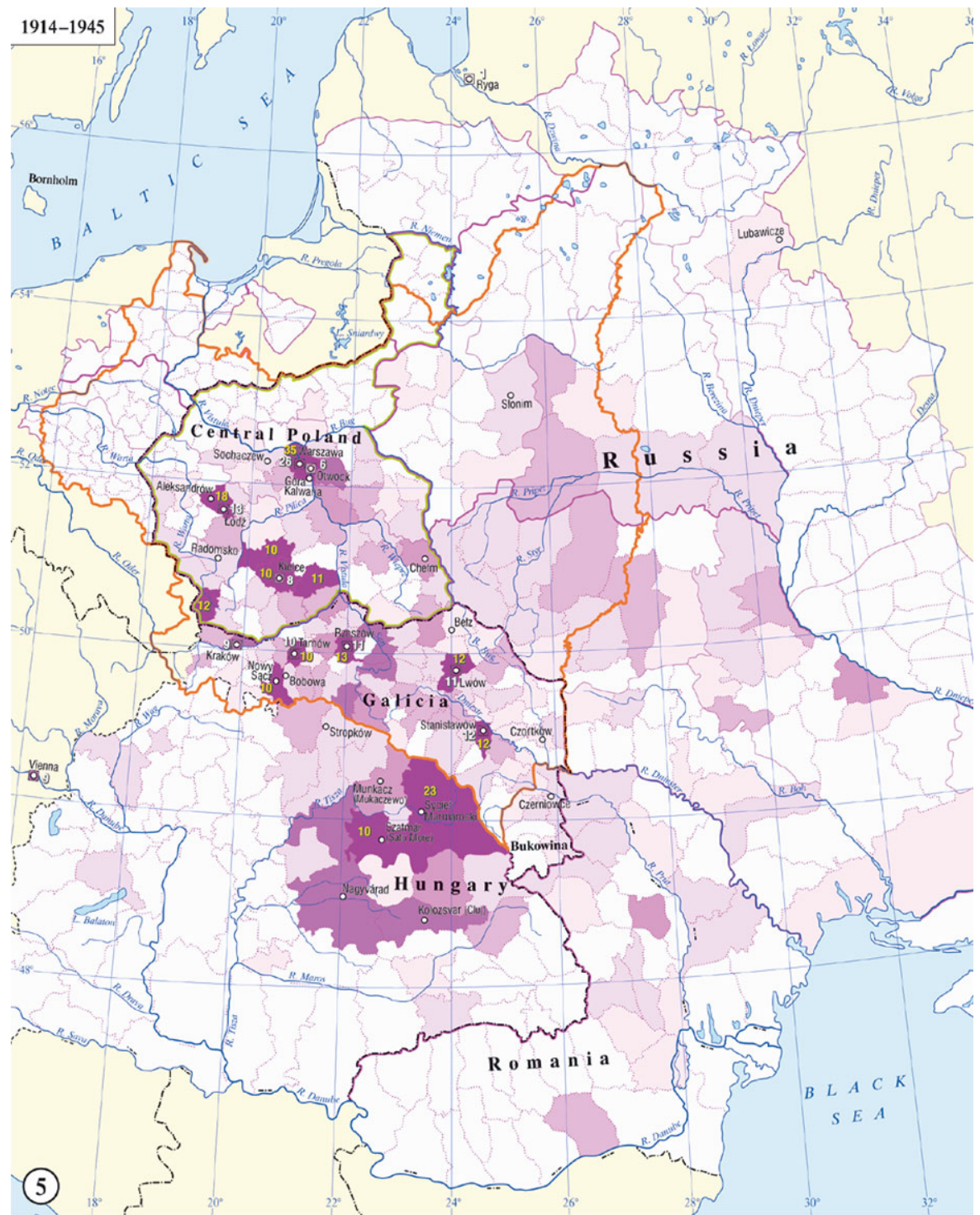

Map 5. Concentration of hasidic leaders by county, after 1914 
maps our data relate to the lowest administrative level of "county" - the only level that was common to all the national territories involved. ${ }^{15}$ This was done in order to capture the circulation of hasidic leaders within the larger territorial units without cluttering the maps with numerous names of villages or towns, which would have been overwhelming. Each of the counties is color-coded to reflect the number of tsadikim residing in it: the darker the color the more numerous the tsadikim.

\section{What Do the Maps Show?}

At first glance, the maps reflect - as reliably as possible, given the limitations of the data at our disposal-no more than variations in the concentration of hasidic leaders by county during five distinct periods in the history of Hasidism. But how should these maps be interpreted? May we draw from them any conclusions that go beyond the changing geographic distribution of the leaders' courts over time? The problem is that there is not a simple correspondence between the density of the courts and the demographic strength or cultural influence of Hasidim in the same area. ${ }^{16}$ For example, Lubawicze, the seat of the Habad dynasty for virtually the whole of the nineteenth century, was the only hasidic court in the Mohylew province (with some sporadic competition from Starosiele and Kopyś), but there is every reason to believe that its demographic and cultural presence was rather strong. ${ }^{17}$ This suggests

Jews. They were designed to meet the requirements for publication in Atlas historii Żydów polskich (Warsaw, 2010) and will eventually be displayed in the Museum of the History of Polish Jews in Warsaw.

${ }^{15}$ In order to avoid confusion, the term "county" will be used consistently for the lowest level of geographical administrative units, and the term "province" for the next level up, encompassing several "counties." "County" corresponds to the Polish powiat, Russian uyezd, German Kreis, Hungarian vármegye, and Romanian judeţ, while "province," which has no directly corresponding level in the Austrian, Hungarian, and Romanian administrations; corresponds to the Russian gubernia and Polish województwo.

${ }^{16}$ The category of "density" is used here as shorthand to denote the number of tsadikim per administrative unit and not per given area.

${ }^{17}$ The Lubavitcher rebbes reportedly attracted hundreds of thousands of followers, but this should be treated as somewhat hyperbolic figurative language. Nevertheless, an abundance of anecdotal material suggests that the dynasty did command mass support in its region. On the difficulty of interpreting demographic data relating to Hasidism, see Marcin Wodziński, "How many Hasidim were there in Congress Poland?"; id., "How Should We Count Hasidim in Congress Poland?"; Glenn Dynner, Men of Silk, 40-53; id. "How Many Hasidim Were There Really in Congress Poland?" For the best estimates of the number of Shneur Zalman of Liady's followers, see, e.g., Immanuel Etkes, "Darko shel rabi shneur zalman milady kemanhig shel hasidim," Zion 50 (1995), 334-41; Naftali Loewenthal, Communicating the Infinite: The Emergence of the Habad School (Chicago, 1990), 47-8. 
that at least some powerful hasidic leaders may have dominated their immediate environment so exclusively as to create an effective power vacuum all round them (the towns in which such well-known hasidic leaders resided are identified on our maps by name). Still, it seems that with a few isolated exceptions, the vast majority of hasidic leaders neither managed nor attempted to gain exclusive control over their regions or even their immediate neighborhoods. Rather, they typically shared the geographic space with a number of competitors. The dominant model, therefore, was of a large number of closely clustered centers, with several hasidic leaders active at the same time, either in the same town or, more often, in a number of neighboring shtetlekh. The general assumption underlying our maps is that the density of such centers reflects, however indirectly, the relative demographic strength of Hasidism in a given region, even if some or perhaps all of the leaders clustered in it had comparatively few followers. Moreover, we believe that the relative insignificance of such leaders does not weaken but, to the contrary, strengthens the close correlation between the number of tsadikim and the strength of hasidic influence in a region. The fact that many such minor tsadikim were functioning simultaneously would suggest that there was intense demand for hasidic leadership in that area, and that people were flocking to these minor tsadikim despite their relatively humble status. We are, of course, aware that this may not always have been the case, as the influence of a single dominant leader could significantly blur or skew the picture. Nevertheless, even if we allow for a certain measure of error on this score, our maps still provide the best approximation, based on the best available data, of the geographical distribution and relative strength of the hasidic movement. Religious leaders are generally located in the midst of their followers, namely, those who are most receptive to their influence and who choose to live in their close proximity. We assume this should apply to the case of the hasidic leaders and their followers as well. What is more, we believe that our maps, and the database they draw on, can facilitate further studies of both the workings of hasidic leadership and the nature of the wider hasidic constituency across eastern Europe.

In the following pages we offer some possible interpretations of our maps, and draw a number of preliminary conclusions from them. We begin with a topic that has always been closely linked to the maps of Hasidism: the parameters (both borders and dynamics) of hasidic expansion in eastern Europe. This is followed by two topics that are less directly related to the maps: the correlation between certain political conditions and the development of Hasidism, and the interrelation between Hasidism and the processes of urbanization and metropolization that eastern European Jewry underwent during the period of hasidic expansion. It should be emphasized that these are only opening gambits that might lead to further research utilizing our data and methodology as a point of departure. 


\section{Borders}

At first glance, the statistical results, divided by country and period, demonstrate growth in terms of a clear rise in the numbers of tsadikim throughout (with the single exception of Russia after 1914, to be discussed below), although this growth is by no means linear, and its dynamics are not the same in every period and region. Our analysis of the variations might thus reveal some inherent characteristics of the "hasidic conquest of Eastern Europe"one of the most commonly observed and yet least understood processes in the history of the movement. What, indeed, were the parameters of the hasidic "conquest"? The maps confirm some common assumptions while revealing new and unexpected realities. Let us start with the issue of borders. The maps clearly confirm the persistence of the eastern border of Hasidism along the eastern frontier of the Polish-Lithuanian Commonwealth (as of 1772), with relatively weak and late incursions into the territories of New Russia and Bessarabia during the second half of the nineteenth century (see Map 4). The maps also confirm the well-established notion that Hasidism did not penetrate the territories that lay beyond the western frontier of Congress Poland and Galicia. There were a few exceptions: the singular case of the tsadik Eliyahu Guttmacher of Grodzisk Wielkopolski (1796-1874), several hasidic émigrés in Germany (Berlin, Magdeburg, Leipzig), and-during the interwar period-Prague and Vienna. This remained true even after 1918, when the nineteenth-century political border ceased to exist and the territories of Poznan province were incorporated in the Second Polish Republic (see Map 5). ${ }^{18}$ What is more, throughout the period under consideration, hardly any hasidic leaders ever resided in the western provinces of Congress Poland, such as Kalisz and Płock. ${ }^{19}$ The Płock province is an especially interesting case, because a period of successful hasidic development there in the first half of the nineteenth century (five tsadikim between 1815 and 1866; see Map 3$)^{20}$ was followed by a sudden and persistent drop (two tsadikim in the period 1867-1914 and only one tsadik after 1914; see Maps 4 and 5). ${ }^{21}$

\footnotetext{
${ }^{18}$ On the western border of Hasidism, see Shaul Stampfer, "How and Why Did Hasidism Spread?" in the present volume.

${ }^{19}$ Until 1914, there were no hasidic leaders in Kalisz province, while after 1918 there were only six minor figures residing in this area, in Wieluń (3), Kalisz (2), and Turek (1). By contrast, at the same time 59 hasidic leaders were active in the territories of the former province of Warsaw.

${ }^{20}$ In 1818 the state authorities in Płock reported that the hasidim "are so numerous that in almost all the towns of the province they have their separate prayer houses" (Archiwum Główne Akt Dawnych, Centralne Władze Wyznaniowe 1869, pp. 8-9).

${ }^{21}$ The small number of hasidim in the region was confirmed in Florian Sokołów's memoir of his father, Nachum Sokołów. See Florian Sokołów, Nahum Sokołów. Życie i legenda, ed. Andrzej Zięba (Kraków, 2006), 22.
} 
This is an intriguing example not only of the failure of Hasidism to expand but of actual hasidic regression, which-in contrast to the case of hasidic decline in Soviet Russia - was unrelated to external political circumstances.

The northern border of hasidic expansion in Congress Poland was demarcated by the province of Płock, where-as we have seen-hasidic leaders failed to establish themselves permanently, and by the southern counties of the province of Łomża (Maków Mazowiecki, Ostrów Mazowiecka). In the greater part of the province of Łomża, to the north of these counties, and in the whole province of Suwałki, there were never any tsadikim or any other prominent hasidic figures (for instance communal rabbis claiming allegiance to Hasidism). The same demarcation line continued into the Pale of Settlement in Russia. Hasidic leaders resided in an area bordered by the southeastern counties of the province of Grodno (Brześć, Kobryń, and Słonim), stretching to the southern border of the province of Wilno and the southern counties of the province of Witebsk. ${ }^{22}$ North of this line, hasidic leaders resided only sporadically (see Maps 2 and 4).

There may be many reasons for the impenetrability of this northern borderline. Undoubtedly, the cultural impact of the Litvak heritage was one of them. Both the northeastern provinces of Congress Poland (Łomża and Suwałki) and all the northwestern provinces of the Pale of Settlement in Russia historically belonged to the Grand Duchy of Lithuania, and in the nineteenth century they remained under the influence of the Lithuanian yeshivot, a cultural alternative to Hasidism. Marvin Herzog's study of the linguistic and cultural boundary between Polish and Litvak Jews convincingly proved the correlation between areas of Litvak tradition and resistance to Hasidism. ${ }^{23}$ However, the origins and nature of this correlation are not obvious (the cultural impact of the Vilna Gaon, usually offered as a self-evident explanation, is certainly not sufficient to account for the Litvak resistance to Hasidism, as it may well have been its product rather than its cause). Moreover, the correlation is not consistent. The territories south of this borderline (the provinces of Mohylew and Mińsk, the southern reaches of the provinces of Grodno and Witebsk) also belonged to the Grand Duchy of Lithuania and remained in the same cultural milieu, and yet a relatively large number of hasidic leaders were active there. The factor that might have been at least partially responsible for this difference was the German cultural influence in the

\footnotetext{
${ }^{22}$ Interestingly, the location of the followers of Hasidism in the southern counties of the province of Witebsk is confirmed, with slightly different borderlines, in a Russian official report from 1853. See Ia[kov] I[zraelson], "Borba pravitelstva s khasidizmom (1834-53 g.)," Evreyskaya Starina 7 (1914), 100. We are grateful to Vladimir Levin for his assistance in deciphering the author's name.

${ }^{23}$ See Herzog, The Yiddish Language, 18-27.
} 
territories bordering the German state. A detailed study of the limited hasidic penetration into Lithuania suggests the importance of the German factor in preventing the expansion of Hasidism into the northern and western regions of Lithuania. ${ }^{24}$ As already hinted by several scholars, areas bordering on German territories and under the cultural influences of German Jewry might have been less receptive to Hasidism. The same explanation may account for the failure of hasidic expansion in the province of Płock. Even if the concept of "Litvak," and especially the notion of German cultural influence are not much more than cultural stereotypes, they may well have had their effect, as the microhistorical analysis of at least one test case would suggest. This is the case of the "German" Jews of Bielsko/Bielitz in Austrian Silesia, whose selfperception as belonging to the sphere of German cultural influence prompted them to resist the settlement of a hasidic leader in their midst. ${ }^{25}$ Cultural stereotypes can be as real as any other factors shaping reality.

Equally intriguing, and more difficult to account for, is the southern border of hasidic expansion. Until 1815 (see Maps 1 and 2) it ran along the southern frontier of the former Polish-Lithuanian Commonwealth (the southern border of Galicia after its annexation to Austria in 1772). Prior to 1815, only three hasidic leaders are known to have been active south of this border: Shalom Teomim (d. 1819) in Ştefăneşti, Moldavia, and Hayim Tirer in Czerniowce, Bukowina (which he left in 1807) — both relatively minor tsadikim, and Yitshak Taub of Nagykallo (1744-1821), an enfant terrible among the hasidic leaders of his time, known for indulging in Hungarian folk-dances and feasting with the Hungarian gentry. After 1815, several hasidic leaders followed in Yitshak's footsteps and crossed the border into Bukowina (at that time formally part of Galicia) and the Hungarian counties of Maramaros, Szabolcs, Bereg, and Zemplen (see Map 3). To be sure, the region remained a marginal area of hasidic expansion, despite the importance of several of its resident tsadikim, especially Israel of Ruzhin in Sadagóra, Bukowina, and Moshe Teitelbaum (1759-1841) in Sátoraljaújhely in the county of Zemplen, Hungary. The 29 tsadikim resident in Hungary, Bukowina, and the Romanian territories constituted no more than 7.1 percent of the hasidic leaders active in that period, but in relation to the size of the Jewish population in the whole of that region, these 29 tsadikim signify a sudden increase. Similarly, the 14 tsadikim active in Hungary represented an average spread of 0.35 tsadikim

\footnotetext{
${ }^{24}$ See Mordechai Zalkin, “'Mekomot shelo matse' ah adayin hahasidut ken lah kelal?' bein hasidim lemitnagedim belita bame' ah ha-19," in Bema 'agelei hasidim: kovets mehkarim lezikhro shel profesor mordekhai vilenski, ed. Immanuel Etkes et al. (Jerusalem, 1999), 21-50.

${ }^{25}$ For a case study of the failed attempt by a hasidic leader, Aron Halberstam of Biała (1865-1942), to cross the cultural border between Galicia and Austrian Silesia, see Marcin Wodziński, "Aron Halberstam z Białej. O wpływach chasydyzmu na pograniczu galicyjskośląskim," in Żydzi w Bielsku, Biatej i okolicy. Materiaty z sesji naukowej odbytej w dniu 19 stycznia 1996 r., ed. Janusz Polak and Janusz Spyra (Bielsko-Biała, 1996), 106-10.
} 
per 10,000 Jews in the population, a sudden rise from 0.08 in the previous period. This trend became even more pronounced in the second half of the nineteenth century (see Map 4). Between 1867 and 1914 as many as 16 hasidic leaders were recorded in Bukowina, 37 in Hungary (mainly Maramaros) and 19 in Romania, which constituted 12.7 percent of all the tsadikim active in this period. Although the relative numbers of hasidic leaders per capita in the Hungarian, Romanian, and Bukowinian Jewish populations were still unimpressive (0.44 tsadikim per 10,000 Jews ca. 1850 and 0.6, ca. 1900), one should remember that the hasidic movement was active only in a relatively small area of Hungary, that is, in the Unterland, and this reduces Hasidism's per capita demographic strength in the whole of Hungary. In the interwar period, the relative importance of Hungarian and Romanian Hasidism became even more apparent, with as many as 193 tsadikim living in the territories of prewar Hungary, Romania, and Bukowina, constituting 20.1 percent of all the hasidic leaders of the period, or, in relative numbers, 1.17 tsadikim per 10,000 Jews living in these regions (see Table 2). By this time, the hasidic movement had not only crossed the southern border of the former PolishLithuanian Commonwealth, but it actually established a new stronghold in these territories. ${ }^{26}$

\section{The Dynamics of Expansion}

As with other parameters, the chronological dynamics of the expansion of Hasidism must be studied with caution, given the limitations of our maps, which are based on data extracted from an encyclopedia drawing, in part, on the collective memory of Hasidism. Collective memory tends to preserve a more precise record of recent events than of the distant past. Consequently, a greater proportion of early hasidic leaders than of those belonging to recent generations is likely to have been forgotten. To take account of this, the data for our five consecutive periods would need to be adjusted, as the number of tsadikim in the earlier periods was probably somewhat higher than these data suggest, and at the very least, it cannot be compared on a one-to-one basis to the number of tsadikim in more recent times. This is especially evident in

\footnotetext{
${ }^{26}$ On hasidic expansion in Hungary and Romania, see, e.g., Michael K. Silber, "The Limits of Rapprochement: The Anatomy of an Anti-Hasidic Controversy in Hungary," Studia Judaica 3 (1994), 124-47; Lucian-Zeev Herscovici, "An Outline of the History of Hasidism in Romania," in The History of the Jews in Romania, ed. Liviu Rotman and Carol Iancu (Tel Aviv, 2005), 2:209-29.
} 
the case of the interwar years: although many reliable historical records from all over eastern Europe testify to a significant decline in hasidic influence, measured by the number of hasidic followers, during those years, the large number of tsadikim featured in the Encyclopedia as being active at that time is completely at odds with the notion that the influence of Hasidism was declining. ${ }^{27}$ And yet, despite these obvious limitations, our data do reveal some genuinely significant long-term trends.

Unfortunately, very little can be said about the dynamics of expansion in the early years of Hasidism's development, until 1772. Although this first period may be the most important for understanding the reality of expansion, the data available are too scarce for a detailed picture of the process to be drawn. The Encyclopedia contains only a few reliable entries relating to this period, indiscriminately listing dozens of supposed adherents of the putative founder of Hasidism, Israel Besht (1700-1760) and his first "apostle," Dov Ber, the Maggid of Mezerich [Międzyrzec Korecki] (d. 1772). Unfortunately, it draws nearly all their names from hagiographic sources, mainly the nineteenth-century collection of tales, Shivhei habesht, and it lists them regardless of their actual relationship to Hasidism.

If we eliminate these unreliable biographical entries, our findings confirm the conventional view of Podolia and Volhynia as the cradles of Hasidism. The largest concentration of recorded leaders appears in the area of Międzybóż in Podolia, with somewhat fewer in Volhynia (Połonne, Korzec, Ostróg, Miedzyrzec Korecki), fewer still in the eastern territories of Red Ruthenia (which became Eastern Galicia in 1772), and only a handful outside of this area (see Map 1).

This concentration of hasidic leaders in Podolia and Volhynia held sway for some time after 1772, but it is worth noting that the number of tsadikim did not increase as rapidly there as it did in Galicia or central Poland. This would seem to suggest a substantial shift in the center of gravity of the hasidic movement, with the newly emergent centers achieving predominance after 1815. Table 1 displays this shift in numerical terms, with southwest Russia standing for the Ukrainian provinces of Podolia, Volhynia, Kijów [Kiev], Połtawa and Czernihów (the latter three still being marginal in this period).

\footnotetext{
${ }^{27}$ The distortion in the numbers for the interbellum years might have resulted from yet another factor, namely, the fact that this period was significantly shorter than the other four featured in the maps. A certain time lag between the drop in the number of hasidic leaders on the one hand, and the consequent drop in the number of hasidic followers on the other, may explain why the decline was not captured by the number of tsadikim per capita.
} 
Table 1. The number of hasidic leaders by country 28

\begin{tabular}{lccccc}
\hline Region & $1700-72$ & $1772-1815$ & $1815-67$ & $1867-1914$ & $1914-45$ \\
\hline $\begin{array}{l}\text { Russia } \\
\quad \text { Including: }\end{array}$ & 13 & 65 & 97 & 139 & 89 \\
$\quad$ Northwest (Lithuania and & 2 & 11 & 29 & 41 & 21 \\
$\quad$ Belarus) & 11 & 54 & 62 & 90 & 57 \\
$\quad$ Southwest (Ukraine) & 0 & 1 & 6 & 8 & 10 \\
$\quad$ South Russia & 1 & 23 & 96 & 165 & 216 \\
Central Poland $^{30}$ & 8 & 33 & 120 & 190 & 247 \\
Galicia $^{31}$ & 0 & 1 & 5 & 16 & 18 \\
Bukowina $_{\text {Hungary }}^{32}$ & 0 & 1 & 14 & 37 & 144 \\
Romania $^{33}$ & 0 & 1 & 5 & 19 & 31 \\
\hline
\end{tabular}

The shift becomes even more evident when it is compared to the estimated size of the Jewish population in each of the six regions. An approximation of the relative number of hasidic leaders per 10,000 Jews is provided in Table 2.

To be sure, the data are imprecise and must be read with caution, but even with this reservation, they point to patterns of development that are sufficiently consistent to be considered as reflecting actual trends.

The first of these is the predominance of Galicia over Russia in terms of the number of hasidic leaders per capita in the Jewish population of the province. This seemed apparent already in the first period (though, as mentioned above, the data for this period are too scarce and imprecise to allow for any firm conclusions) and became very noticeable in the period between 1772 and 1815. It has to be remembered, however, that the overall figures for Russia include the Lithuanian-Belarussian territories (known as the northwest), where the hasidic presence was sparse, together with the Ukrainian territories (the southwest), where there were many more hasidic communities. If we break down the Russian territories into their three constituent major regions, we obtain a more realistic picture, with the number of hasidic leaders per capita in the southwestern provinces (Podolia, Volhynia, Kijów

\footnotetext{
${ }^{28}$ For the sake of consistency and comparability, the table anachronistically applies the political divisions of 1815-1914 to other periods, too.

${ }^{29}$ Excluding the territories of Congress Poland, and after 1918, referring to the territories of Soviet Russia as well as the former Russian voivodships of the Second Polish Republic (again, without Congress Poland), in addition to Lithuania, Latvia, and Romanian Bessarabia.

${ }^{30}$ The territories of Congress Poland.

${ }^{31}$ Without Bukowina.

${ }^{32}$ Including territories annexed in 1918 to Czechoslovakia and Romania.

${ }^{33}$ Before 1878, the territories of Moldavia, Transylvania, and Wallachia. After 1918, without the territories annexed from Austro-Hungary and Russia.
} 
Table 2. The approximate number of hasidic leaders per 10,000 Jewish inhabitants by country ${ }^{34}$

\begin{tabular}{llllll}
\hline Region & $\begin{array}{l}1700-72 \\
\text { (ca. 1764) }\end{array}$ & $\begin{array}{l}1772-1815 \\
\text { (ca. 1800) }\end{array}$ & $\begin{array}{l}1815-67 \\
\text { (ca. 1850) }\end{array}$ & $\begin{array}{l}1867-1914 \\
\text { (ca. 1900) }\end{array}$ & $\begin{array}{l}1914-45 \\
\text { (ca. 1930) }\end{array}$ \\
\hline $\begin{array}{l}\text { Russia } \\
\quad \text { Including: }\end{array}$ & 0.46 & 0.87 & 0.57 & 0.39 & 0.28 \\
$\quad$ Northwest (Lithuania and & 0.1 & 0.33 & 0.39 & 0.29 & \\
$\quad$ Belarus) & & & & & \\
$\quad$ Southwest (Ukraine) & 0.65 & 2.40 & 0.81 & 0.63 & \\
$\quad$ South Russia & 0 & 0.29 & 0.30 & 0.11 & \\
Central Poland & 0.05 & 0.64 & 1.68 & 1.25 & 1.31 \\
Galicia & 0.59 & 1.65 & 3.60 & 2.34 & 3.13 \\
Bukowina & 0 & 3.33 & 3.33 & 1.67 & 1.96 \\
Hungary & 0 & 0.08 & 0.35 & 0.45 & 1.08 \\
Romania & 0 & 0.33 & 0.37 & 0.71 & 1.19 \\
\hline
\end{tabular}

[Kiev], Połtawa, and Czernihów) being higher than their number per capita in Galicia during the 1772-1815 period. Very soon afterwards, however, Galicia reached numbers that far exceeded not only the numbers for Russia in general but also for the cradle of Hasidism in the southwestern Russian provinces of Podolia and Volhynia.

In central Poland, the number of hasidic leaders was still smaller than in Russia, and far lower than in Galicia, but it was growing rapidly, while in Bukowina, Hungary, and the Romanian territories of Moldavia and Wallachia, there were hardly any hasidic leaders at this point, which confirms the presumption of a relatively late hasidic expansion into these territories.

The period after 1815 is distinguished by the most remarkable transformations in the internal geography of Hasidism, and may be considered the heyday of hasidic expansion in eastern Europe. A new center was emerging in Hungary and Romania (see the discussion above), and the absolute dominance of Galicia had become firmly established, with many more tsadikim than in any other area. These two factors together made for a southwestern shift, from the Ukrainian provinces of the Russian Empire, which had been Hasidism's center of gravity during the eighteenth century, to Galicia in the

\footnotetext{
${ }^{34}$ As in Table 1, political divisions dating from the period 1815-1914 are applied anachronistically to all the other periods, too. Since there are no reliable demographic data for the period prior to the end of the nineteenth century, the calculations here are based on various estimations and are to be treated as mere approximations. For the period 1700-72, see Raphael Mahler, Yidn in amolikn Poyln in likht fun tsifrn (Warsaw, 1958); for the 1930s, see Ezra Mendelsohn, The Jews of East Central Europe between the World Wars (Bloomington, 1983) and Materialy $i$ issledovaniya, vol 4: Evrei v SSSR (Moscow, 1929). We are grateful to David Rechter for his assistance in gathering demographic estimations for Bukowina.
} 
course of the nineteenth century, and to Hungary and Romania in the interwar period.

The data for Galicia are especially revealing, as the per capita calculation for ca. 1850 yields as many as 3.6 tsadikim per 10,000 Jews in the population. This amounts to approximately one tsadik for each seven hundred adult Jewish men. Admittedly, the calculation is misleading in some respects and has to be corrected accordingly, ${ }^{35}$ but even when all the necessary adjustments have been made, the number of adult Jewish men per tsadik living in Galicia ca. 1850 appears to have been no more than 1,500 - a surprisingly low figure, which might force us to revise our long-held assumptions about the nature and functioning of the hasidic leadership, and its relation to the hasidic community, at least during this period in Galicia (on which see the discussion below). The data are especially striking if we take it into account that not all the Galician Jews at the time were hasidic; that there were some tsadikim in Galicia (for instance the Bełz and Nowy Sacz dynasties) whose influence, which exceeded that of many others, left little scope for their competitors to recruit their own adherents; and that the distribution of tsadikim in Galicia had always been uneven, with high concentrations in some areas and virtually no tsadikim in others. ${ }^{36}$ All this raises the question of the size of the hasidic following affiliated to an average hasidic court in Galicia. If it was as small as is suggested by the calculations above, one wonders what the economic and social standing of such a court might have been, and whether a minor tsadik, who had no more than one or two hundred followers traveling to him once or twice a year, could have been sustained by the donations (pidyonot, ma'amadot, and other contributions) he received from his

\footnotetext{
${ }^{35}$ For example, the demographic value for ca. 1850 gives the false impression that all the hasidic leaders who were active at various times throughout the whole period from 1815 to 1867—more than fifty years encompassing approximately two generations-were operating at one and the same time. To correct this distortion and obtain a more realistic estimate, this value should be reduced by a factor of two. Moreover, as was noted above, we have counted as hasidic leaders not only full-fledged tsadikim but also communal rabbis affiliated with Hasidism, who constitute approximately 10 percent of our database. Consequently, with respect to the number of potential followers per actual tsadik, the demographic values we present must be further reduced by 10 percent.

${ }^{36}$ Compare, for example, the almost total absence of tsadikim in the counties south of Kraków (Żywiec, Biała, Limanowa, Myślenice, Wieliczka, and Nowy Targ), and their relatively weak presence in the counties situated along the eastern frontier of Galicia (Zbaraż, Skałat, Borszczów, Zaleszczyki) and west of Lwów (Żółkiew, Gródek, Jaworów), with the areas of high concentration of hasidic leaders, especially along the frontier between Western and Eastern Galicia (in Dzików, Leżajsk, Łańcut, Przeworsk, Jarosław, Sieniawa, Bełżec, Cieszanów, Lubaczów, Narol, Przemyśl, Dynów, Rymanów, Krosno, Dukla, Ustrzyki, Lesko, and Lutowiska), in Pokucie (Kosów, Nadwórna, Horodenka), and along the central Dniestr River (Komarno, Żydaczów, Strzeliska, Buczacz).
} 
hasidim. Indeed, what political influence might such a tsadik have exerted on his followers and, more importantly, on the community in which he lived? We should remember that under the impact of hasidic hagiography, where all the tsadikim are glorified indiscriminately, and on the basis of the reputations of a few particularly illustrious tsadikim, historians have often assumed that every hasidic leader exercised absolute control over his community. While this may have been the case with some tsadikim in the major courts, especially those located in small towns such as Bełz or Góra Kalwaria, is it right to attribute the same powers to hundreds of lesser hasidic leaders?

The data presented above further raise the question of the nature of hasidic organization at the local community level. Since the followers of many minor tsadikim were unlikely to be in a position to establish their own local shtiblekh, which would be dedicated exclusively to their own rebbe, we should consider the possibility that hasidic prayer houses regularly accommodated the adherents of more than one rebbe. ${ }^{37}$ If this was the case then the shtibl must have been a far more diversified institution than is commonly assumed. ${ }^{38}$ Finally, the figure of approximately 1,500 adult Jews per tsadik in mid-nineteenth century Galicia raises the question of the real parameters of hasidic dominance. It seems reasonable to assume that the lower the number of hasidim per rebbe, the greater the extent of hasidic penetration and thus dominance. If the number of adult Jewish men per tsadik could be as low as about 1,500 , then we should ask what level of penetration by hasidic leaders is required for Jewish society in a given territory to be considered as having come under hasidic domination. Would approximately 8,000 adult Jewish men per tsadik in early nineteenth-century central Poland, or about 13,000 per tsadik in Russia at the turn of the twentieth century be enough to claim hasidic dominance in these territories?

The data also reveal a dramatic increase in the number of hasidic leaders in central Poland, which after 1815 was officially named the Kingdom of Poland but became better known as Congress or Russian Poland. With 96 tsadikim amounting to 1.68 per 10,000 Jews, Congress Poland in this period

\footnotetext{
${ }^{37}$ This assumption finds strong support in memoir literature (see, e.g., Yekhezkel Kotik, A Journey to a Nineteenth-Century Shtetl: The Memoirs of Yekhezkel Kotik, ed. David Assaf, trans. Margaret Birstein [Detroit, 2002], 203) and numerous yizkor books (see, e.g., Yaakov Gorali [Gruzhelko], "Pirkei historyah vezikhronot," in Kartuz-bereza: sefer zikaron ve 'edut likehilah shehushmedah hi"d, ed. Hayim Ben Israel [Tel Aviv, 1993], 15; Dov Brukash, "Khsidim-shtiblekh un khsidim in Tshizheve," in Izker-bukh nokh der khorev-gevorener yidisher kehile Tshizheve, ed. Shimon Kants [Tel Aviv, 1961], 185-6).

${ }^{38}$ For initial research on the shtibl, see Marcin Wodziński, Hasidism and Politics: The Kingdom of Poland 1815-1864, trans. Sean Martin (Oxford and Portland, 2013), chap. 6; Shaul Stampfer, "How and Why Did Hasidism Spread?" in the present volume.
} 
achieved a degree of penetration that was almost three times higher than in the previous period.

In Russia during the same period, the absolute number of tsadikim went up from 65 to 97 . This moderate rise, together with the much higher rate of demographic growth in the Jewish population, accounts for the decline in the relative number of tsadikim, from 0.87 to 0.57 per 10,000 Jews living in the Pale of Settlement. For the first time since the beginning of Hasidism, the constant rise in the number of hasidic leaders in Russia appears to have been arrested. By the next period represented on our maps, this stagnation was to turn into a steep decline, highlighting the emergence of Galicia as the region showing the highest degree of hasidic penetration.

Most importantly, and despite the evident stagnation in Russia, when the data for 1815-67 are compared with the data for both the preceding and the subsequent periods, they suggest that the expansion of the hasidic leadership in eastern Europe reached its peak around the middle of the nineteenth century. At no other time, either before or after, did the hasidic movement as represented by the presence of tsadikim achieve such a high degree of penetration into Jewish society. Although absolute numbers continued to rise in the later period, the number of tsadikim relative to the size of the total Jewish population never reached and, in fact, fell much below what it had been in $1815-67$.

The changes reflected in the data for our next two maps are fewer and not as significant as those for the period ending in 1867. The decline in the relative number of hasidic leaders per capita in all major areas of hasidic diffusion between 1867 and 1914 was important, but most other trends marking the previous periods seem to have persisted unchanged. The relatively precise demographic data for the period around 1900 allow us to sketch several of these in some greater detail. The concentration of hasidic leaders in Galicia was somewhat lower than in the previous period (possibly as a result of especially dynamic demographic growth in this period), but still reached the very high value of 2.34 tsadikim per 10,000 Jewish inhabitants. As many as 33.6 percent of all the tsadikim of the period lived in Galicia. At the same time, proportions per capita in the Russian Pale of Settlement fell much below the average Galician figures, with 0.63 tsadikim per 10,000 Jewish inhabitants in the Southwest, and as little as 0.29 in the Northwest (see Table 3). Of all the Russian territories, the highest concentration was recorded in the province of Volhynia, with 0.88 tsadikim per 10,000 Jewish inhabitants, amounting to only one-third of the Galician value. In Podolia there were as few as 0.49 tsadikim per 10,000 Jews, with not a single one of them sufficiently influential to create a power vacuum around him. It thus seems certain that in the course of the nineteenth century, Podolia ceased to be the stronghold of the hasidic movement, at least in terms of the number of hasidic leaders residing in the province (see Map 4). 
At the same time, in the Russian provinces of Kijów [Kiev] and Mińsk, the number of tsadikim in relation to the size of the Jewish population reached 0.81 and 0.74 respectively per 10,000 Jews. This easily overtook the figures for the province of Podolia, and approached the figures for the province of Volhynia. The high values for Kijów and Mińsk, together with the corroborative evidence of the memoir literature, suggest that the hasidic movement had indeed achieved a relatively strong position in this area. ${ }^{39}$ The dominance of the Chernobyl [Czarnobyl] dynasty and its numerous offshoots may have contributed to the success of Hasidism in this region, but other factors may have been at play, and the phenomenon needs to be investigated much more carefully. ${ }^{40}$

In terms of the proportion of hasidic leaders, Congress Poland around 1900 was much closer to the Galician than the Russian model. The provinces of Radom and Kielce had 2.21 and 2.19 tsadikim per 10,000 Jews respectively, values which are close to the average for Galicia (2.34), and much higher than any of the values for the provinces of the Pale of Settlement. Other central-Polish provinces had far lower values (to be discussed below), but the average figure for Congress Poland (1.25) was still far higher than for the Pale (0.39), indicating the growing importance of this area for the hasidic movement. It is also interesting to note that some memoir sources confirm that at the beginning of the twentieth century, Podolia and Volhynia were much less hasidic than Congress Poland. ${ }^{41}$

The data for individual provinces (gubernias) are presented in Table 3.

The data for the fifth period, 1914-45, testify to the large scale migration taking place, both internally, within Eastern Europe, and overseas, where new hasidic centers (excluded from the present discussion) were being established in the United States, Great Britain, and elsewhere in western Europe. For the eastern European territories under consideration, the data also demonstrate a significant shift in the regions under dominant hasidic influence. The number of tsadikim in Romania, and especially in Hungary, rose significantly and turned both territories into principal areas of hasidic domination, ranking

\footnotetext{
${ }^{39}$ About Konotop, see, e.g., Pauline Wengeroff, Rememberings: The World of a RussianJewish Woman in the Nineteenth Century, trans. Henny Wenkart, ed. Bernard D. Cooperman (Bethesda, 2000), 154. About Vasilkov, see Yekhezkel Kotik, Na venad: zikhronotav shel yekhezkel kotik, trans. David Assaf (Tel Aviv, 2005), 2:230. Both were in the province of Kijów and, according to both memoirists, they were nearly entirely hasidic.

${ }^{40}$ For the Chernobyl dynasty's geographical dimensions, see Gad Sagiv, "Hasidut chernobil: toledoteiha vetoroteiha mereshitah ve 'ad erev milhemet ha'olam harishonah" (PhD diss., Tel Aviv University, 2009), chap. 3.

${ }^{41}$ See, e.g., Israel Joshua Singer, Of a World That Is No More, trans. Joseph Singer (New York, 1970), 16-7.
} 
Table 3. Hasidic leaders per capita by province of Russian Empire, ca. 1900

\begin{tabular}{|c|c|c|c|}
\hline Region & $\begin{array}{l}\text { Number of Jewish } \\
\text { inhabitants, } 1897^{42}\end{array}$ & $\begin{array}{l}\text { Number of hasidic } \\
\text { leaders active in the } \\
\text { province between } \\
1867 \text { and } 1914\end{array}$ & $\begin{array}{l}\text { Number of hasidic } \\
\text { leaders per } 10,000 \\
\text { Jewish inhabitants } \\
\text { in } 1897\end{array}$ \\
\hline Bessarabia & 226,000 & 5 & 0.22 \\
\hline Cherson & 337,000 & 3 & 0.09 \\
\hline Jekaterynosław & 101,000 & 0 & 0 \\
\hline Crimea & 66,000 & 0 & 0 \\
\hline \multicolumn{4}{|l|}{ Total for } \\
\hline South Russia & 730,000 & 8 & 0.11 \\
\hline Grodno & 277,000 & 10 & 0.36 \\
\hline Kowno & 212,000 & 0 & 0 \\
\hline Mińsk & 339,000 & 25 & 0.74 \\
\hline Mohylew & 201,000 & 5 & 0.25 \\
\hline Witebsk & 176,000 & 1 & 0.06 \\
\hline Wilno & 205,000 & 0 & 0 \\
\hline \multicolumn{4}{|l|}{ Total for the } \\
\hline Northwest & $1,410,000$ & 42 & 0.30 \\
\hline Czernihów & 115,000 & 2 & 0.17 \\
\hline Kijów & 428,000 & 35 & 0.81 \\
\hline Połtawa & 111,000 & 0 & 0 \\
\hline Podolia & 367,000 & 18 & 0.49 \\
\hline Wolhynia & 398,000 & 35 & 0.88 \\
\hline \multicolumn{4}{|l|}{ Total for the } \\
\hline Southwest & $1,418,000$ & 87 & 0.61 \\
\hline Kalisz & 72,000 & 0 & 0 \\
\hline Kielce & 82,000 & 18 & 2.19 \\
\hline Lublin & 154,000 & 25 & 1.62 \\
\hline Łomża & 91,000 & 4 & 0.44 \\
\hline Piotrków & 222,000 & 34 & 1.53 \\
\hline Płock & 50,000 & 2 & 0.4 \\
\hline Radom & 113,000 & 25 & 2.21 \\
\hline Siedlce & 122,000 & 18 & 1.47 \\
\hline Suwałki & 59,000 & 0 & 0 \\
\hline Warszawa & 350,000 & 39 & 1.11 \\
\hline \multicolumn{4}{|l|}{ Total for } \\
\hline Congress Poland & $1,316,000$ & 165 & 1.25 \\
\hline
\end{tabular}

just below the leading position of Poland. This accounts for the somewhat Hungarian flavor of Hasidism's impressive rehabilitation in its new centers

\footnotetext{
${ }^{42}$ Based on B. Goldberg, "Zur Statistik der jüdischen Bevölkerung in Russland laut der Volkszählung von 1897," in Jüdische Statistik, hrsg. vom Verein für Jüdische Statistik unter der Redaktion von Dr. Alfred Nossig (Berlin, 1903), 259-86.
} 
in Israel, the United States, and western Europe after World War II and the Holocaust. ${ }^{43}$

The most striking phenomenon in the interwar period was, however, the dramatic drop in the number of tsadikim in Russia, especially during the third decade of the century (see below), which reflected the virtual extinction of the movement in this region, and anticipated similar developments in other eastern European territories, brought on by the Holocaust. The map for this period demonstrates clearly the hasidic leadership's move out of the Soviet territories of the former Pale of Settlement and its concentration in the Second Republic of Poland (see Map 5).

\section{Politics and the Geography of Expansion}

Careful examination of the maps reveals a close correlation between the boundaries of the hasidic conquest and the shifting political borders of the eastern European states. Let us examine two striking cases.

The first and most obvious is the abrupt decline in the number of hasidic leaders in the territories of Russia after 1914 (see Map 5 and Table 1). This was a result not only of the massive dislocation that occurred during World War I and its aftermath (including the pogroms that erupted toward the end of the second decade of the century), but especially of the anti-religious policies adopted by the new Soviet regime after 1918, when religious authorities and institutions were being hounded and suppressed. Although little of these events, other than the odyssey of the Lubavitcher Rebbe, Yosef Yitshak Schneersohn (1880-1950), has attracted scholarly attention, ${ }^{44}$ the map testifies to the consistency, large scale, and ultimate effect of this persecution.

Another interesting correlation between the dynamics of hasidic expansion and the legal-political framework can be observed in the territories of central and western Poland. In the period until 1772 there were hardly any hasidic leaders in this territory (see Map 1), but during the 1772-1815 period, there emerged a concentration of hasidic leaders in the territories east of the Pilica River (see Map 2; for instance, Kozienice, Przysucha, Opatów). This

\footnotetext{
${ }^{43}$ On the prominence of the Hungarian courts in post-Holocaust Hasidism, see, e.g., Janet S. Belcove-Shalin, ed., New World Hasidim: Ethnographic Studies of Hasidic Jews in America (New York, 1995); Jerome R. Mintz, Hasidic People: A Place in the New World (Cambridge, 1992).

${ }^{44}$ On the fate of the hasidic movement, especially its leadership, under the Soviet regime, see, e.g., David E. Fishman, "Preserving Tradition in the Land of Revolution: The Religious Leadership of Soviet Jewry, 1917-30," in The Uses of Tradition, ed. Jack Wertheimer (New York, 1992), 85-118; Shalom D. Levin, Toledot habad berusyah hasovyetit: 1918-1950 (New York, 1989).
} 
can be partly explained by the cultural borders of Hasidism: much of the territories west of this area belonged to Wielkopolska (Greater Poland), where the small size of the Jewish population, its concentration in the cities and larger towns rather than in shtetlekh, which did not exist in this region, together with the strong cultural influences of German Jewry, dictated a significantly lower pace of hasidic infiltration. Similarly, the northeastern territories (Suwałki) dominated by Lithuanian Jewry were closer to the mitnagdic than the hasidic way of life. But these social, demographic, and cultural factors cannot fully account for the striking difference between the high number of hasidic leaders in the region east of the Pilica River and the significantly lower number in several other areas of central Poland, which were socially, demographically, and culturally identical with the area east of the Pilica River, such as eastern and western Mazovia or northern and southern Podlasie.

Why was Hasidism more successful in the territories east of the Pilica River? The only factor that seems to be relevant is politics. In 1793-95, central Poland was divided between Prussia and Austria. Wielkopolska, part of Mazovia, northern Podlasie, and the western borderlands of Małopolska (Lesser Poland) west of the Pilica River, as well as the Siewierz principality, fell to Prussia in the second (1793) and third (1795) partitions. Austria, which did not participate in the second partition of 1793, acquired part of Mazovia, the Sandomierz region, southern Podlasie, and the Lublin region, which in 1795 constituted the territory known as Western Galicia. It seems that Austrian rule was the factor that facilitated the success of Hasidism in these territories. ${ }^{45}$ The density of hasidic leaders in Western Galicia distinguished it from other regions of central Poland and put it on a par with central areas of Eastern Galicia, which had already come under Austrian rule in 1772. What is more, the high concentration of hasidic leaders in all these territories remained in force during the subsequent periods, when Western Galicia ceased to exist, and they were incorporated into Congress Poland. The dissolution of the older phantom cultural-political borders was a longdrawn process, which was not completed until the twentieth century (see Table 3 above). As late as 1900, the concentration of hasidic leaders per 10,000 Jews in the former Austrian territories of Congress Poland (for instance, 2.21 in the province of Radom, 2.19 in the province of Kielce, and 1.62 in the province of Lublin) was far higher than in the former Prussian territories (for instance, 0.4 in the province of Płock and 1.11 in the province of Warsaw). It seems that the political and/or legal conditions prevailing under Austrian

\footnotetext{
${ }^{45}$ It is not our intention to dwell here on the specific features of Austrian rule that might have been conducive to the development of Hasidism, or at least to the settlement of numerous hasidic leaders within its borders. For more on this, see Rachel Manekin, "Hasidism and the Habsburg Empire, 1788-1867" in the present volume.
} 
rule may have continued to shape the geography of Hasidism even after the geopolitical circumstances changed at the turn of the nineteenth century, with Prussian rule over these territories ending in 1807, and Austrian rule ending in 1809 .

\section{Hasidism and Urbanization}

Another remarkable phenomenon highlighted by the maps is the urbanization of the hasidic leadership. There had always been a few tsadikim who settled in large Jewish communities, for example, in Czerniowce [Czernowitz], Lwów, and Kraków; but until the end of the nineteenth century, these were isolated cases, which sparked heated debate and comment in hasidic literature, as in the case of Yaakov Yitshak Horowitz, the Seer of Lublin (17451815 ), or else ended with the tsadik's withdrawal into a smaller shtetl, as in case of Yitshak Meir Alter of Ger [Góra Kalwaria] (d. 1866). ${ }^{46}$ Until 1914 semi-urban shtetlekh and, to a lesser degree, middle-size towns (often with shtetl-like Jewish districts) were clearly the settlements of choice for hasidic leaders. Only after 1914 did numerous tsadikim begin to settle in the great modern urban centers of eastern Europe (see map 5). The most spectacular case was Warsaw, where as many as 26 hasidic leaders resided during the interwar period, with Łódź showing a somewhat smaller but still impressive concentration of 13 leaders.

Hasidic leaders moved not only to the metropolitan cities of central Poland, such as Warsaw and Łódź, but also to many provincial cities, especially in Galicia, where there were no major metropolitan centers. Stanisławów (with 12 hasidic leaders), Lwów (11), Rzeszów (11), Tarnów (10), and Kraków (9) were especially popular in this respect. Undoubtedly, this massive resettlement was largely a response to the atrocities of World War I, which had left a particularly painful mark on Galicia. Twice occupied by the Russians, the local population, Jewish and non-Jewish alike, was forced to flee persecution by the military authorities. Some Jews (including many tsadikim) fled as far as Vienna; many others found shelter in the large urban Jewish communities of Galicia, where they remained even after World War I and the subsequent Polish-Ukrainian, Polish-Soviet, and SovietUkrainian wars were over. The same war-time hardships may have drawn

\footnotetext{
${ }^{46}$ For such comments on the settlement of Yaakov Yitshak Horowitz in Lublin, see e.g., Moshe Menahem Walden, Nifle'ot harabi (Warsaw, 1911), 13, 75, 86; Tsvi Meir Rabinowicz, Bein pshyskha lelublin (Jerusalem, 1997), 110-2. For documents on the opposition to Yitshak Meir Alter's activities in Warsaw, see Zofia Borzymińska, "Sprawa Rabiego Icchaka Meira Altera," Biuletyn Żydowskiego Instytutu Historycznego 52 (2001), 3:367-77; Marcin Wodziński, Hasidism in the Kingdom of Poland, 1815-1867: Historical Sources in the Polish State Archives (Kraków, 2011), chap. 36.
} 
many refugees into Warsaw and Łódź, where Jews felt relatively safer than in their small home communities, where they had been exposed to the whims and ill-will of local military commanders and their under-fed and unremunerated troops.

The persistent phenomenon of the tsadikim's urban resettlement after the wars suggests that it resulted from other factors in addition to the warinduced difficulties. Was it a side-effect of the generally shifting settlement patterns of the Jewish population in an age of industrialization and urbanization? Were the hasidic leaders merely following their adherents who, in search of new economic opportunities, migrated in their tens of thousands from small nineteenth-century shtetlekh to the newly emergent, large, urban centers of the early twentieth century? Jacob Shatzky, attempting to explain how Warsaw came to be dominated by Hasidism, once suggested that in reality, Warsaw Jews never became hasidim but rather many hasidim became residents of Warsaw. ${ }^{47}$ The settlement pattern of the hasidic leadership seems to support the validity of this observation not only for Warsaw but also for many other east European cities. However, it seems that the shift in the settlement pattern of the hasidic leadership occurred later than that of the hasidic rank and file. Hasidic leaders tended to move to the big city during World War I and the interwar period, long after hasidic dominance in Warsaw and elsewhere had been established.

\section{Conclusions}

The geography of Hasidism has always attracted the attention of both historians and adherents of the movement. The notions of the hasidic map developed by these two constituencies have had much in common, as they were derived primarily from hagiographical sources reflecting the apologetic tendencies of their hasidic authors. Our own maps represent an attempt to free hasidic geography from this tradition. As already noted, they do not altogether overcome the elitist bias of the available research on the social history of Hasidism, which focuses on the hasidic leaders to the virtual exclusion of the rank-and-file followers of the movement. Ideally, the geography of Hasidism should be reconstructed on the basis of a much wider range of sources, including not only hasidic materials but also official reports, memoirs, yizkor books, the Jewish press, and prenumeranten lists for hasidic publications printed in Europe, although even this may not be sufficient to capture the complex dynamics of hasidic expansion. For the time being, however, we have expanded the relevant database, eliminated the subjective judgment that

\footnotetext{
${ }^{47}$ See Yaakov Shatzky, Geshikhte fun Yidn in Varshe, vol. 3 (New York, 1953), 352.
} 
had traditionally determined its scope, and proposed a new conceptualization of the hasidic leadership and its following in eastern Europe. Though some of our observations, such as the failure of Hasidism to spread beyond its western borders, might be common knowledge (albeit hitherto unverified), others provide new insights into the history of the hasidic movement and point in the direction of new research agendas. These include, for example, the apparent shift of hasidic centers from Podolia and Volhynia in the eighteenth century to Galicia and the southeastern provinces of Congress Poland in the nineteenth century, and subsequently to Hungary and Romania in the twentieth century; the hasidic penetration into Jewish eastern Europe reaching its peak specifically in the period between 1815 and 1867; or the metropolization of the hasidic leadership after 1914. We hope that our maps will stimulate others to pursue this field of investigation, propose additional new insights, and — where necessary—refine or correct our findings. 